\title{
Öğretimsel Dokümanlardaki Etkinliklerin Amaçlarının Ortaokul Matematik Öğretmenlerinin Perspektifinden İncelenmesi
}

\section{Mehmet Güzel$^{1} \quad$ Ali Bozkurt ${ }^{2} \quad$ Mehmet Fatih Özmantar $^{3}$}

\section{Type/Tür:}

Research/Araştırma

Received/Geliş Tarihi: December

31/31 Aralık 2019

Accepted/Kabul Tarihi: February

7/7 Şubat 2020

Page numbers/Sayfa No: $875-896$

Corresponding

Author/Iletişimden Sorumlu

Yazar: alibozkurt@gantep.edu.tr

\section{$\checkmark$ iThenticate}

This paper was checked for plagiarism using iThenticate during the preview process and before publication. / Bu çalışma ön inceleme sürecinde ve yayımlanmadan önce iThenticate yazılımı ile taranmıştır.

Copyright (c) 2017 by Cumhuriyet University, Faculty of Education. All rights reserved.

\section{Öz}

$\mathrm{Bu}$ çalışmada ortaokul matematik öğretmenlerinin öğretimsel dokümanlardaki etkinliklerin amaçlarını nasıl algıladıkları incelenmiştir. Araştırmanın katılımcıları, Türkiye'nin güneyindeki bir devlet üniversitesinde lisansüstü eğitime devam etmekte olan 15 ortaokul matematik öğretmenidir. Öğretmenlerin Mesleki deneyimleri 1 ile 6 yıl arasında değişmektedir. Bu araştırma betimsel bir çalışmadır. Çalışmanın verileri, katılımcılara etkinlik tasarımı ve uygulamaları ile ilgili herhangi bir eğitim verilmeden toplanmıştır. Veri toplama aracı olarak katılımcılara ders kitaplarından rastgele seçilmiş dört etkinliğin yer aldığı bir form dağıtılmıştır. $\mathrm{Bu}$ etkinliklerin her birinin amacını yazmaları istenmiştir. Elde edilen veriler nitel analiz yöntemlerinden içerik ve betimsel analiz yöntemleri ile analiz edilmiştir. İçerik analizlerinden elde edilen bulgulara göre aynı etkinliğin amacının öğretmenlere göre çeşitlilik gösterdiği görülmüştür. Betimsel analizlerden elde edilen bulgulara göre ise katılımcıların cevaplarının bilişsel talep düzeylerine göre sınıflandırma bağlamında farklı sınıflarda değerlendirilebilecek tarzda oldukları görülmüştür. Öğretmenlerin verilen bir etkinliğin amacını birbirinden farklı algılamaları, etkinliğin uygulanma amaçlarının farklı olabileceği şeklinde yorumlanabilir. Ayrıca, farklı öğretmenle eğitim gören öğrencilerin farklı öğrenme çıtıları olabilir. Bu ise aynı eğitim süreçlerinden geçen öğrencilerin ilgili matematiksel kavramlara ilişkin farklı bilişsel düzeylerde olmalarına sebep olabilir. Buradan hareketle etkinliğin bir araç olarak değerlendirilip amacının da buna dönük belirlenmesinin ve vurgulanmasının gerekliliği ortaya konulmuştur. Özellikle, ders kitaplarında verilen etkinliklerle neyin amaçlandığının daha açık ve anlaşılır bir şekilde ifadesinin önemi ortaya çıkmaktadır.

Anahtar Kelimeler: Öğretimsel doküman, öğretimsel etkinlik, etkinliğin amacı, bilişsel talep düzeyi, öğretmen görüşleri

\section{Suggested APA Citation / Önerilen APA Atıf Biçimi:}

Güzel, M., Bozkurt, A., \& Özmantar, M.F. (2020). Öğretimsel dokümanlardaki etkinliklerin amaçlarının ortaokul matematik öğretmenlerinin perspektifinden incelenmesi. Cumhuriyet International Journal of Education, 9(3), 875-896. http:/ / dx.doi.org/10.30703/cije.668064

\footnotetext{
${ }^{1}$ Dr, Sani Konukoğlu Ortaokulu, Şehitkamil, Gaziantep/Türkiye Title, Sani Konukoğlu Elementary School, Şehitkamil, Gaziantep/Turkey e-mail: mmtgzl1@gmail.com, ORCID ID: orcid.org/0000-0003-1551-9641

2 Prof. Dr., Gaziantep Üniversitesi, Gaziantep Eğitim Fakültesi Gaziantep/Türkiye

Prof, Gaziantep University, Gaziantep Education Faculty „, Gaziantep/Turkey e-mail: alibzkrt@gmail.com, ORCID ID: orcid.org/0000-0002-0176-4497

${ }^{3}$ Prof. Dr., Gaziantep Üniversitesi, Gaziantep Eğitim Fakültesi Gaziantep/Türkiye

Prof, Gaziantep University, Gaziantep Education Faculty „, Gaziantep/Turkey

e-mail: mfozmantar@hotmail.com, ORCID ID: orcid.org/0000-0002-7842-1337
} 


\title{
An Investigation of Text Book Activities' Purposes from the Perspective of Mathematics Teachers
}

\begin{abstract}
This study aims to examine how mathematics teachers perceive the purposes of text book activities. The participants include 15 secondary school math teachers enrolled in a Master program at a state university in the south of Turkey. The professional experience of the participants varies from 1 to 6 years. The study was designed as a descriptive research. The data were collected from participants before they attended to a course about design and implementation of activities. As a data collection tool, participants were given a form with four randomly selected text book activities and asked to write the purposes for each of these activities. Among the qualitative analysis methods, the content and descriptive analysis methods were used to analyze the data. The content analysis revealed that teachers had disparate perceptions about the purposes of the same activity. On the other hand, according to the results obtained from the descriptive analyses, it was established that the answers of the participants could be categorized in different levels in terms of classification according to cognitive demand levels. Teachers' varying perceptions of the purposes of a given activity can be attributed to the fact that the activity was designed and implemented for different purposes. In addition, students taught by different teachers may have different learning outcomes. This may cause the students who go through the same educational processes to be at different cognitive levels for the relevant mathematical concepts. On that basis, it has been put forward how important it is to perceive activities as a tool, and to determine and highlight their objectives accordingly. Especially with the activities given in textbooks, the importance of expressing the purpose of the activity in a clearer and more understandable way emerged.
\end{abstract}

Keywords: Instructional documents, activity, purpose of activity, cognitive demand level, teacher's perceptions

\section{Giriş}

Öğretim sürecinde etkinlik, hem öğretim dokümanlarında hazırlanan ve yazılı olarak sunulan görevler dizisini hem de bu görevler dizisinin uygulanmasını karşılayan bir kavram olarak kullanılmaktadır (Swan, Bell, Phillips ve Shannon, 2000). Ders kitapları ve diğer öğretimsel kaynaklarda yer alan çeşitli etkinlikler ile öğrencilerin öğrenme sürecinde zihinsel ve fiziksel olarak aktif olmaları beklenmektedir. Böylece, öğrencilerin sorumluluk alan, sorgulayan, düşünen, tartışan, anlayan, problem çözebilen, problem kurabilen ve birlikte çalışabilen bireyler olarak yetişmelerine katkı sunulması hedeflenmektedir (Bozkurt ve Kuran, 2016).

Etkinlik tasarlama ve uygulama sürecinde önemli öğelerden biri, yapılacak etkinliğin amacıdır (Özmantar ve Bingölbali, 2009). Bir etkinliğin amacı, etkinliğin tasarımını ve uygulanmasını etkilemektedir. Ayrıca etkinliğin tasarlanması, uygulanması ve değerlendirilmesi aşamalarında da etkinliğin amacı yol gösterici olmaktadır. Dolayısıyla, etkinliğin amacının iyi belirlenmediği durumlarda sürecin verimli olması beklenemez (Özgen, 2017). Etkinliğin amacı, Swan ve arkadaşları (2000) tarafından etkinliğin görünen amacı veya öğrenciler tarafından algılanan amacı ve öğretmenin etkinliği uygulamadaki amacı olmak üzere iki perspektiften değerlendirilmiştir. Özmantar ve Bingölbali (2009) ise etkinliğin amacından bahsederken etkinliğin tasarlanma amacı, öğrenme çıktıları veya kazanımlar içindeki yeri ve öğrencinin algılayacağı amaçtan bahsetmektedir. Coles ve Brown (2006) öğretmenlerin etkinlikten bekledikleri sonuçlarla öğrencilerin amaçlarının 
farklılaşabildiğini belirterek bu uyuşmazlıkların en aza indirilmesi için bazı prensipler sunmuştur. Bu araştırmanın odağı gereği bu prensiplere girilmeyecektir. Ancak söz konusu çalışmada da öğretmen ve öğrencilerin etkinliği uygulamadaki amaçlarında meydana gelen farklılaşmadan bir sorun olarak bahsedilmektedir. Bu bakımdan bir etkinlikte iki türlü amaçtan söz edilebilir. Birincisi, etkinliği tasarlayanın veya uygulayan kişinin güttüğü amaç olan düşünsel amaçtır. İkincisi ise etkinliğin uygulama sürecinde öğrencinin veya etkinliğe muhatap olanın ulaşmak istediği nokta olan eylemsel amaçtır. Etkinliğin başında öğrencilerin düşünsel amacın ne olduğunu bilmeleri gerekmez. Ancak öğrencilerin eylemsel amaçtan habersiz olmaları alan yazında, uygulama aşamasında etkinliğin amacıyla ilgili olmayan yönleri ile ilgilenme veya yüzeysel yönlerine odaklanarak esas noktayı kaçırma ihtimalleri nedeniyle etkinliği zayıflatan bir durum olarak vurgulanmıştır (Swan ve ark., 2000). Dolayısıyla etkinlik sürecinin başında, tasarlanacak veya seçilecek etkinliğin düşünsel ve eylemsel amaçlarının belirlenmesi önem arz etmektedir. Yani öğretmen (etkinliği uygulayan) açısından etkinliğin düşünsel amacının, öğrenci (etkinliğe muhatap olan) açısından ise eylemsel amacın açık olması gerekir. Bir öğretim etkinliğinin amacını birkaç farklı perspektifte değerlendirmek mümkündür:

- Etkinliğin müfredatın kazanımları içerisindeki yeri

- Etkinliğin tasarlanma amacı

- Öğretmenin etkinliği yapmadaki amacı

- Öğrencinin etkinliği yapmadaki amacı

Alan yazında eğitim öğretim sürecinde öğretmen beklentileri, sınıfın sosyokültürel ve sosyo-matematiksel normları, öğrencilerin beklentileri, ilgi ve önbilgileri gibi birçok faktörün süreç üzerinde önemli rolü olduğuna dair birçok çalışma yapılmıştır (Henningsen ve Stein,1997; Dweck, 2000; Rollard, 2012; Ainley ve Margolinas, 2013). Eğitim öğretim sürecinin önemli bir parçası olan etkinliklerde de etkinliğin amacına dair öğrencilerin algılarının süreç üzerinde etkisinin olacağ belirtilmektedir (Ainley ve Margolinas, 2013). Alan yazında etkinlik uygulaması esnasında öğretmenlerin ve öğrencilerin alg1 ve beklentilerinin birbirinden farklı olduğu ifade edilmektedir (Newman, Griffin ve Cole, 1989; Stein ve ark., 1996; Swan, 2000). Bu bakımdan öğrencilerin etkinlik uygulaması esnasında öğretmenin amacından farklı bir amaç taşıyabileceği söylenebilir. Konu ile ilgili bu çalışmalarda öğretmenin ve etkinliği tasarlayanın (eğer etkinlik hazır olarak alınmış ise) aynı amacı taşıyacakları varsayılmıştır. Oysa, öğretmenin etkinliğin amacını doğru bir biçimde anlayacağı veya tasarlandığı amaç doğrultusunda kullanacağını varsaymak her zaman doğru olmayabilir. Stein, Grover ve Henningsen (1996), bir etkinliğin öğretimsel materyallerde sunulan halinin, öğretmenlerce uyarlanan veya algilanan halinden farklı olabileceğini, uygulama aşamasında öğrencilerin yaptıklarının ise öğretmenin tasarladığından farklı olabileceğini belirtmektedir. Dolayısıyla, etkinliği tasarlayan ile uygulayanın daima aynı amaçları taşıyıp taşımadıklarının da araştırılması gerekmektedir.

Etkinliklerin kitaplarda veya diğer kaynaklarda tasarlanan halinin, sirasıyla öğretmen tarafından sınıfa uyarlanan ve sınıfta uygulanan haline gelme aşamalarından geçip öğrencilerin öğrenmesinin gerçekleşme sürecini Stein ve Smith (1998) şekil 1'deki gibi bir modelle göstermiştir. 


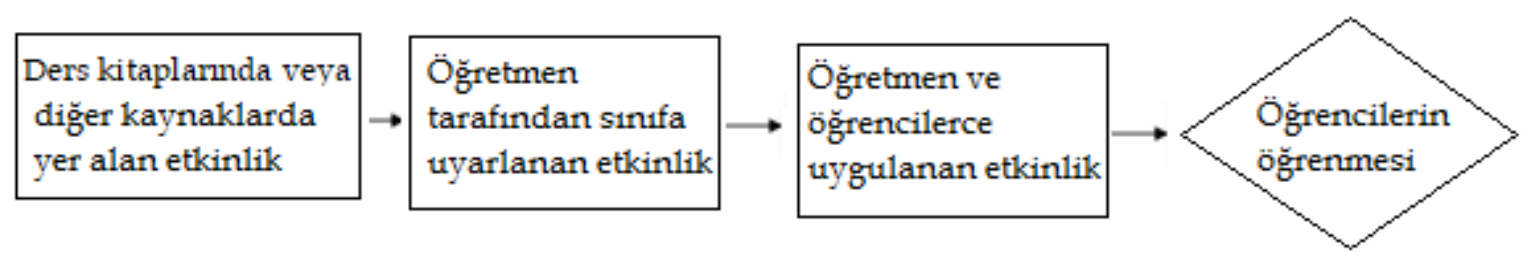

Şekil 1. Öğretimsel etkinliklerin tasarım ve uygulama süreçlerindeki dönüşümü (Stein ve Smith, 1998)

Öğretmenin öğretimsel dokümanlarda yer verilen etkinlikleri seçme veya yaptığ1 revizyonlarda etkinliği uygulamadaki amacı belirleyici olurken, öğretmenin konu alanı bilgisi ve öğrencileri ile ilgili bilgileri sürecin niteliğini belirlemektedir. (Stein, Grover ve Henningsen, 1996). Uygulama aşamasında ise sınıf içi normların, etkinlik uygulama prensiplerinin, öğretmenin öğretimsel alışkanlık ve eğilimlerinin ve öğrencilerin öğrenme alışkanlıkları ve eğilimlerinin etkili olduğunu savunulmaktadır (Stein ve Smith, 1998). Anlaşıldığı üzere etkinlik tasarlandığ1 gibi kalmamakta ve öğrenciye ulaşana kadar bazı değişimlerden ve revizyonlardan geçmektedir. Bu değişim ve revizyonlar kimi zaman etkinliğin uygulanma biçimi veya kullanılacak materyaller ile ilgili olurken kimi zaman ise etkinliğin amacıyla ilgili olabilmektedir. Etkinlikler Stein ve arkadaşları (1996) tarafından, etkinliğin özelliği ve etkinliğin bilişsel talebi olmak üzere iki perspektiften değerlendirilmektedir.

Bir etkinlikteki bilişsel talep düzeyi, ilk defa Doyle' da (1983) dile getirilmiş olup, Stein ve ark. (1996) çalışması ile önemli ölçüde bugün kabul gören halini almıştır. Daha sonra yapılan çalışmalarda da sıklıkla referans verilen (örneğin Swan, 2000; Clarke ve Roche, 2018) ve etkinliklerin niteliklerinin tespit edilmesinde de kullanılan bilişsel talep düzeyleri yüksek ve düşük bilişsel talep seviyelerinden oluşmakta ve her biri için alt seviyeler tanımlanmaktadır. Bu çalışma kapsamında da etkinliklerin amaçlarının sinıflandırılmasinda kullanılacak Stein ve Smith'ten (1998) uyarlanan bu seviyeler; ezberleme, bağlantısız işlemler, bağlantılı işlemler ve matematik yapma olarak tanımlanmıştır. Verilen seviyelerden ezberleme seviyesindeki etkinlikler, önceden öğrenilen bilgilerin tekrarına dayanır ve üzerinde çalışılan kavramın anlamını bilmeyi gerektirmez (Stein ve ark., 1996). Bağlantısız işlemler seviyesi, bir problemin çözümü için kullanılan algoritmanın nasıl ve neden işe yaradığını bilmeden problemleri çözmeyi içermektedir (Stein ve ark., 1996). Bahsedilen iki seviye düşük düzeydeki bilişsel talep seviyelerini ifade etmektedir. Yüksek seviyedeki bilişsel talep düzeylerinden bağlantılı işlemler seviyesinde öğrencilerin problem çözerken kullandıkları bir genel yöntem vardır ancak bu yöntem çok geneldir ve altında yatan matematiksel kavramlar ve fikirler ile ilişki kurmayı gerektirmektedir. Matematik yapma seviyesinde ise tahmin edilebilir genel bir çözüm yöntemi olmayan problemler içeren etkinlikleri ifade etmektedir (Stein ve ark., 1996).

Matematik ders kitapları başta olmak üzere birçok dokümanda verilen etkinliklerin amaçlarının ne olduğu belirtilmemiştir (Bozkurt, 2018). Dolayısıyla öğretmenlerin öğretimsel dokümanlarda hazır olarak sunulan etkinliklerin amaçlarını doğru algılayacakları varsayımının geçerli olup olmadığı dikkate değer bir nokta olarak karşımıza çıkmaktadır. Başka bir ifade ile öğretmenlerin hazır etkinliklerin amaçlarını belirleme veya hazırlanan bir etkinliğin hangi amaçlar doğrultusunda kullanılmaya uygun olacağı noktalarındaki becerilerinin ortaya konması önemlidir. $\mathrm{Bu}$ kapsamda bu çalışmanın amacı, ortaokul matematik öğretmenlerinin verilen bir 
etkinliğin düşünsel amacını nasıl algıladıklarını ortaya koymaktır. Bu amaç doğrultusunda çalışmada cevaplanacak araştırma sorusu şu şekilde belirlenmiştir:

- Öğretmenler öğretimsel dokümanlarda verilen etkinliklerin düşünsel amaçlarını nasıl algılamaktadırlar?

- Öğretmenlerin öğretimsel dokümanlarda verilen etkinliklerin düşünsel amaç algıları bilişsel talep düzeyine göre farklılaşmakta mıdır?

$\mathrm{Bu}$ çalışmanın amaç cümlesinden anlaşıldığı üzere çalışmanın odağı, öğretmenlerin etkinlik ile ilgili yazdıkları amaçların kritiğini yaparak uygunluğunu tespit etmekten ziyade öğretmenlerin bir etkinliğin amacına dair düşüncelerinin birbirlerinden farklılaşıp farklılaşmadığını ortaya koymaktır. Etkinliklerin amaçlarının ve uygulama biçimlerinin öğretmenin benimsediği öğretim yaklaşımı veya öğrenme teorisi ile değişeceği ve uygulamanın farklılaşacağı vurgulanmaktadır (Kieran Doorman ve Othani, 2013). Dolayısıyla öğretmenlerin, kendilerine sunulan etkinliklerin amaçlarını nasıl algıladıkları ve söz konusu etkinlikleri hangi amaçlar doğrultusunda kullanmaya uygun bulduklarının ortaya konması önemli görülmektedir.

Matematik eğitimi bağlamında etkinlik kavramına akademik ilginin yoğun olduğu yapılan çalışmaların sıklığı ile görülebilmektedir (Daher, Anabousy, Jabarin, 2018; Younger, 2018). Benzer şekilde matematik eğitimi alan yazınında etkinlik tasarlama ve uygulama başlıklarının yıllarda önemli bir artış gösterdiği görülmektedir (Kieran Doorman ve Othani, 2013; Komatsu ve Jones, 2019). Literatürde etkinlik üzerine yapılan çalışmalar incelendiğinde kavramsal olarak etkinlik (Choy, 2018; Yeo, 2007; Doyle, 1983), etkinlik tasarım ve uygulama prensipleri (Ainley ve Margolinas, 2013; Clarke ve Roche, 2018; Coles ve Brown, 2015; Liljedahl, Chernoff ve Zaskis, 2007; Watson, 2016; Watson ve Othani, 2015), ders kitaplarında verilen etkinliklerin değerlendirilmesi (Bayazit, 2013; Bozkurt, 2018; Kerpiç ve Bozkurt, 2011; Özgeldi ve Esen, 2010), öğretmenlerin etkinlik kavramı ve etkinlik temelli eğitim bağlamında alg1 ve becerileri (Bozkurt, 2012; Choy, 2016; Uğurel, Bukova-Güzel ve Kula, 2017), etkinliklerin uygulanmasında ortaya çıkan öğrenci ve öğretmen rolleri, alg1 ve beklentileri (Stein ve Smith, 1998; Özmantar ve Aslan, 2017 ), etkinliklerin bilişsel talep düzeyleri (Stein ve ark., 2000; Ubuz ve Sarpkaya, 2014; Reçber ve Sezer, 2018) gibi bir çok yönden inceleyen çalışmalara rastlamak mümkündür. Ancak etkinliklerin düşünsel amaçlarının uygulayıcıya göre değişip değişemeyeceğine dair çalışmalara çok az rastlanmaktadır (Henningsen ve Stein, 1997). Yapılan çalışmalar teorik düzeyde olup araştırmaya dayalı verilere dayanmamaktadır. Bu yönüyle çalışmanın alan yazına katkı sunması beklenmektedir.

\section{Yöntem}

Bu çalışma betimsel bir araştırmadır. Betimsel araştırmalar halen mevcut olan bir olgu veya olayı var olduğu şekliyle tasvir etmek için kullanılır. Bu tür çalışmalarda araştırma konusu birey veya nesneler kendi koşulları içinde ve olduğu gibi tanımlanır, herhangi bir şekilde değiştirme ve/veya etkileme çabası gösterilmez (Frankel, Wallen ve Hyun, 2011: 15). Bu çalışmada ortaokul matematik öğretmenlerinin öğretimsel dokümanlarda verilen etkinliklerin amaçlarını nasıl algıladıkları ve bu algıların bilişsel talep düzeylerine göre farklılaşıp farklılaşmadı̆̆ı araştırılmıştır. Araştırma kapsamında ilerleyen bölümlerde detaylandırılacağı üzere halen görev yapan 
öğretmenlere Milli Eğitim Bakanlığı Talim ve Terbiye Kurulu (MEB TTK) tarafından onaylanan ders kitaplarında yer alan etkinlikler verilerek amaçlarını yazmaları istenmiştir. Çalışmanın verileri öğretmenlere etkinlik tasarımı ve uygulamaları ile ilgili herhangi bir eğitim verilmeden toplanmıştır. Bu bakımdan araştırmanın verilerinin otantik ortamlardan ve kaynaklardan elde edildiği söylenebilir. Dolayısıyla çalışmanıın doğası betimsel araştırmaya uygundur.

\section{Çalışma Grubu}

Çalışmanın katılımcıları 2018-2019 eğitim öğretim yılı güz döneminde matematik eğitimi alanında yüksek lisans programına devam eden 5'i erkek, 10'u kadın olmak üzere toplam 15 ortaokul matematik öğretmenidir. Mesleki deneyimleri 1 ile 6 y1l arasında değişmektedir.

\section{Veri Toplama Araçları ve Analiz Süreci}

Çalışma kapsamında MEB TTKB tarafından ortaokul matematik ders kitabı olarak okutulmasına dair onay verilmiş kitaplardan rastgele seçilmiş 4 etkinlik ve "Verilen etkinliklerin her birinin size göre amacını yazınız." yönergesinin yer aldığı yazılı bir form hazırlanmıştır. Bu form pilot çalışması kapsamında 5'i kadın, 3'ü erkek olmak üzere 8 ortaokul matematik öğretmenine uygulanmıştır. Pilot uygulamaya katılan öğretmenlerin mesleki deneyimleri 2 ila 5 yıl arasında değişmektedir. Pilot uygulama doğrultusunda formda anlaşılmayan bir durumun olmadığ görülmüştür. Form, öğretmenlere tek seferde ve bir arada oldukları bir ortamda uygulanarak veriler toplanmıştır. Uygulama sürecinde süre kısıtlamasına gidilmemiştir.

Verilerin amacı belirleme ve bu amaçların kategorize edilmesi aşamalarında nitel veri analiz yöntemlerinden içerik analizi yöntemi; yazılan amaçların bilişsel talep düzeylerine göre sınıflandırılmasında ise betimsel analiz yöntemi kullanılmıştır. Betimsel analizlerde elde edilen veriler, daha önceden belirlenen tema, kategori veya kodlar altında özetlenir ve yorumlanır. İçerik analizinde ise araştırmacılar tarafından analizler sonucunda kod veya kategoriler oluşturularak analiz yapılır (Robson, 2009). İçerik analizleri çerçevesinde her bir etkinlik katılımcıların belirledikleri amaçlar açısından analiz edilmiştir. Daha sonra, bu amaçlar kategorilere ayrılmıştır. Oluşturulan kategoriler incelendiğinde birinci etkinlik için 6, ikinci etkinlik için 5, üçüncü etkinlik için 10, dördüncü etkinlik için 8 kategori oluşturulmuştur. Bazı katılımcı cevapları birden fazla kategoride değerlendirilmiştir. Bulgular kısmında her bir öğretmene göre etkinliklerin amaçları yazılmış ve bu amaçlar bağlamında oluşturulan kategoriler verilmiştir.

Aynı kategoride değerlendirilmelerine rağmen bilişsel olarak farklı sınıflara işaret eden katılımcı cevapları olup olmadığına da bakılmıştır. Bu bağlamda yapılan betimsel analizler çerçevesinde, her bir etkinlik için katılımcıların belirledikleri amaçlar, bilişsel talep düzeylerine (Stein ve Smith, 1998) göre analiz edilmiştir.

\section{Güvenirlik}

Verilerin güvenirliği kapsamında her bir etkinliğin amacına dair veriler, öğretmenlerin cevaplarından değiştirmeden alınarak tablolara yazılmıştır. Daha sonra, katılımcı cevaplarında verilen amaçlar çerçevesinde her bir araştırmacı tarafından bağımsız olarak kategoriler oluşturulmuştur. Oluşturulan kategoriler karşılaştırıldığında birinci etkinlik için araştırmacılardan birinin "milyonlar bölüğünü 
okur" diğerinin "7, 8 ve 9 basamaklı sayıları okur” şeklinde yazdığı kategorinin 7,8 ve 9 basamaklı sayıları okur şeklinde yazılmasına karar verilmiştir. Ayrıca "milyonlar basamağının yeri" kategorisinin "basamak ve bölükleri fark etme" kategorisinden ayrı olarak yazılması üzerinde uzlaşılmıştır. Bunların dışında kalan kategorilerde (tüm etkinlikler için) farklı kelimelerle ifade edilen durumlar olmakla birlikte kategorilerin uyuştuğu tespit edilmiştir. Daha sonra, her bir araştırmacı bağımsız bir şekilde katılımcıların cevaplarının tamamını, oluşturulan kategorilere göre analiz etmiştir. Yapılan karşılaştırmada uyum yüzdesinin \%92,4 olduğunu tespit etmişlerdir. Bu oran, Miles ve Huberman (1994)'te verilen oranın üzerinde olduğu için güvenilir kabul edilmiş ancak uyuşmayan cevaplarda üzerinde uzlaşmaya varılana kadar tartışılmıştır.

Ayrıca, cevapların bilişsel talep düzeylerine göre analizi kapsamında öğretmenlerin yazdıkları amaçların hangi kategoride değerlendirilebileceğine dair iki uzman bağımsız olarak amaçları bilişsel talep düzeylerine göre kodlamıştır. Daha sonra, sonuçlar karşılaştırılmış ve uyuşum yüzdesi \%92 olarak hesaplanmıştır. Bu oran, yeterli kabul edilmesine rağmen (Miles ve Huberman, 1994) uzmanlar anlaşamadıkları kodlarda uzlaşılıp ortak bir karara varmışlardır.

\section{Bulgular}

$\mathrm{Bu}$ bölümde, katılımcı öğretmenlerin verilen etkinliklerin amaçlarına dair cevaplarından edinilen verilerden elde edilen bulgulara yer verilmiştir.

\section{Etkinlik 1'e dair Bulgular}

Etkinlik 1, ortaokul 5. sınıf ders kitabının "doğal sayılar" başlığ1 altında ve konunun girişinde verilmiştir.

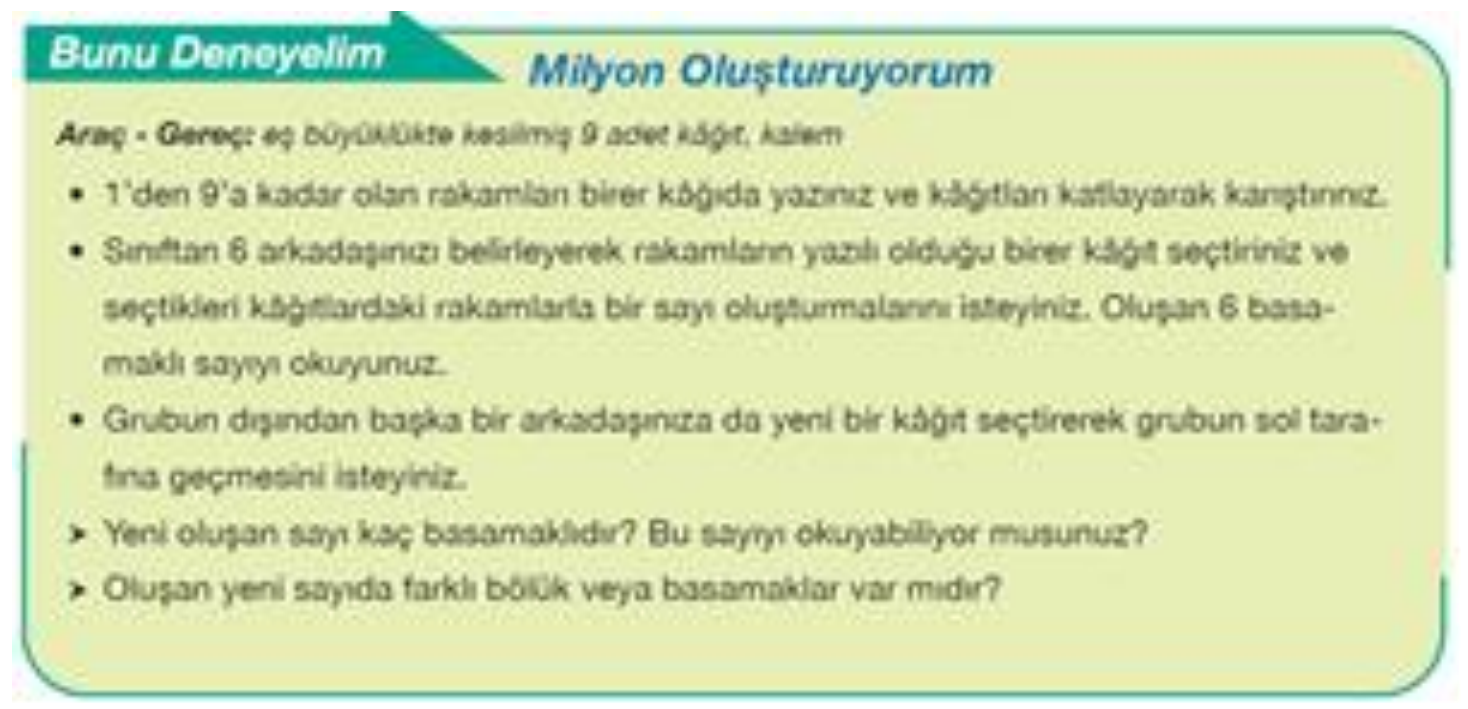

Etkinlik 1. (MEB, 2018, s.13)

Katılımcıların Etkinlik 1'in amacına dair verdikleri cevaplar incelendiğinde genellikle milyonlar bölüğü ile ilgili ifadelerin yazıldığı görülmektedir. Verilen cevapların kategorilere ayrılmış hali Tablo 1'de verilmiştir. 
Tablo 1

Etkinlik 1'in Amacma dair Verilen Cevaplarm Kategorileri

\begin{tabular}{|c|c|c|c|}
\hline Kategori & Katılımcılar & $\mathbf{N}$ & Örnek cevaplar \\
\hline $\begin{array}{l}7,8 \text { ve } 9 \text { basamaklı } \\
\text { sayıları okuma }\end{array}$ & $\begin{array}{l}\text { Ö6, Ö7, } \\
\text { Ö10, } \\
\text { Ö11, Ö13 }\end{array}$ & 5 & $\begin{array}{l}\text { 7, 8, } 9 \text { basamaklı sayıların okunması basamakların ve basamak } \\
\text { değerlerini öğrenmesi.(Ö6) } \\
\text { Etkinlik de milyonlu sayıların okunmasının öğrencilere öğretimi } \\
\text { amaçlanmıştır.(Ö7) } \\
\text { En çok } 9 \text { basamaklı doğal sayıları okuyabilme sayıların } \\
\text { basamaklarını ve bölüklerini kavrama/yorumlayabilme (Ö10) } \\
\text { 5. sınıf milyonları okur kazanımına yönelik derse başlangıç } \\
\text { etkinliği (Ö11) } \\
\text { 5. sınıflara milyonlar basamaklarını ve bölüklerini öğretmek. } 9 \\
\text { basamaklı sayıları okur ve yazar kazanımın öğretmek. (Ö13) }\end{array}$ \\
\hline $\begin{array}{l}6 \text { basamaklı } \\
\text { sayıları okuma }\end{array}$ & Ö3, Ö9, Ö15 & 3 & $\begin{array}{l}6 \text { basamaklı sayıları yazabilmesi ve okuyabilmesi amaçlanmıştır. } \\
6 \text { basamaktan büyük sayıları farkına varması ve bölük } \\
\text { kavramını soruda kullanabilmesi amaçlanmıştır.(Ö3) } \\
\text { Altı basamakh sayıları okunuşu yapar. (Ö9) } \\
6 \text { basamaklı sayıları okuyabilme ve bölüklerine ayırabilme.(Ö15) }\end{array}$ \\
\hline $\begin{array}{l}\text { Milyonlar } \\
\text { bölüğünü } \\
\text { kavratma }\end{array}$ & $\begin{array}{l}\text { Ö4, Ö8, } \\
\text { Ö10, Ö13 }\end{array}$ & 4 & $\begin{array}{l}\text { Milyonlar bölü̈̆̈̈nün oluşturulması ve basamakların fark } \\
\text { ettirilmesi (Ö8) }\end{array}$ \\
\hline $\begin{array}{l}\text { Milyonlar } \\
\text { bölüğünün yerini } \\
\text { söyleyebilme }\end{array}$ & Ö12 & 1 & $\begin{array}{l}\text { Milyonlar bölüğünün yüzbinler bölüğ̈̈nden sonra geldiğini } \\
\text { söyleyebilme.(Ö12) }\end{array}$ \\
\hline $\begin{array}{l}\text { Milyonlar } \\
\text { bölüğünü fark } \\
\text { ettirme }\end{array}$ & $\begin{array}{l}\text { Ö1, Ö3, Ö8, } \\
\text { Ö14 }\end{array}$ & 4 & $\begin{array}{l}\text { Milyonlu sayıları fark ettirme kavranıp kavranmadığını kontrol } \\
\text { etme bölük ve basamak adlarını açılama.(Ö1) } \\
\text { Milyonlar basamağını keşfetmesini sağlamak sayıları basamak } \\
\text { ve bölüklere ayırmak.(Ö14) }\end{array}$ \\
\hline $\begin{array}{l}\text { Sayıları basamak } \\
\text { ve bölüklerini } \\
\text { öğretme }\end{array}$ & $\begin{array}{l}\text { Ö1, Ö 4, Ö6, } \\
\text { Ö9, Ö10, } \\
\text { Ö14 }\end{array}$ & 6 & $\begin{array}{l}\text { Milyonlar basamağın ve milyonlar bölüğ̈̈nü öğrencilere } \\
\text { kavratmak.(Ö4) }\end{array}$ \\
\hline Diğer & Ö2, Ö 5 & 2 & $\begin{array}{l}\text { Etkinliği anlaşılır bulmadım etkinliğin vermek istediği kazanımı } \\
\text { anlamadım.(Ö2) } \\
\text { Sağdan sola her sayıda okunuşlarındaki farklılıkta bölüklerinin } \\
\text { farklı olduğunu kavratmak. (Ö5) }\end{array}$ \\
\hline
\end{tabular}

Tablo 1 incelendiğinde katılımcılardan cevaplarından 5'inin dokuz basamağa kadar olan sayıları okuma kategorisinde değerlendirilirken 3'ünün yalnızca 6 basamaklı sayıları okuma kategorisinde değerlendirildiği görülmektedir. 4'er katılımcının cevabının milyonlar bölüğünü kavratma ve fark ettirme kategorisinde, 6 katılımcının cevabı ise sayıların basamak ve bölüklerini öğretme kategorisinde olduğu görülmektedir. Diğer kategorisindeki Ö2 anlaşııı bulmadığını ve amacını belirleyemediğini ifade ederken Ö5'in yazdığı cümle anlaşılmamaktadır.

Aynı kategoride değerlendirilmelerine rağmen farklı bilişsel talep düzeylerine işaret eden katılımcı cevapları olduğu görülmüştür. Örneğin; Ö8 ve Ö4 aynı kategoride değerlendirilen cevaplar vermişlerdir. Ö4: milyonlar basamağını ve milyonlar bölüğünü öğrencilere kavratmak şeklinde cevap vermiştir. Bu cevap, bilişsel talep düzeyleri bakımından ezberleme kategorisinde değerlendirilmiştir. Ancak Ö8 etkinliğin amacını: milyonlar bölüğ̈̈nün oluşturulması ve basamakların fark ettirilmesi şeklinde açılamıştır. Bu cevapla öğretmenin milyonlar bölüğünü öğrencilere fark ettirmeyi ve oluşturtmayı amaçladığı görülmektedir. Dolayısıyla, bu cevap matematik 
yapma kategorisinde değerlendirilmiştir. Bu kapsamda, Etkinlik 1'in amacına dair verilen cevapların bilişsel talep düzeylerine göre sınıflara ayrılmış hali Tablo 2' de verilmiştir.

Tablo 2

Etkinlik 1'in Bilişsel Talep Düzeylerine Göre Katılımo Cevaplarının Analizi

\begin{tabular}{lll}
\hline Bilişsel talep düzeyi & Katılımcılar & N \\
\hline Ezberleme & Ö4, Ö6, Ö7, Ö9, Ö11, Ö12, Ö13, Ö15 & 9 \\
Bağlantısız işlemler & - & 0 \\
Bağlantılı işlemler & Ö1, Ö3, Ö10 & 2 \\
Matematik yapma & Ö8, Ö14 & 2 \\
Anlaşılmayan & Ö2,Ö 5 & 2 \\
\hline
\end{tabular}

Tablo 2 incelendiğinde Etkinlik 1'in amacına dair katılımcı cevaplarının ezberleme seviyesinde yoğunlaştığı görülmektedir (9 katılımc1) ancak Tablo 1 ve Tablo 2 beraber değerlendirildiğinde etkinliğin amacı için aynı kategoride cevap veren öğretmenlerin bazılarının farklı bilişsel talep seviyesinde etkinliği değerlendirdikleri görülmektedir. Örneğin, etkinliğin amacını 7, 8 ve 9 basamaklı sayıları okuma kategorisinde yazan 5 katılımcı (Ö6, Ö7, Ö10, Ö11 ve Ö13) etkinliğin bilişsel talep düzeylerinde verdikleri cevapların farklılaştığı görülmektedir. Ö6, Ö7, Ö11 ve Ö13'ün cevabı ezberleme seviyesinde değerlendirilmiştir. Benzer şekilde, etkinliğin amacını milyonlar bölüğünü kavratmak olarak yazan Ö4 ve Ö3 ezberleme, Ö10 bağlantılı işlemler, Ö8 ise matematik yapma seviyesinde değerlendirilen cevaplar vermişlerdir.

\section{Etkinlik 2'ye dair Bulgular}

Etkinlik 2, Ortaokul 6. Sınıf ders kitabının “Tam sayılarda toplama işlemi” başlığ altında ve konunun sonunda yer almaktadır.

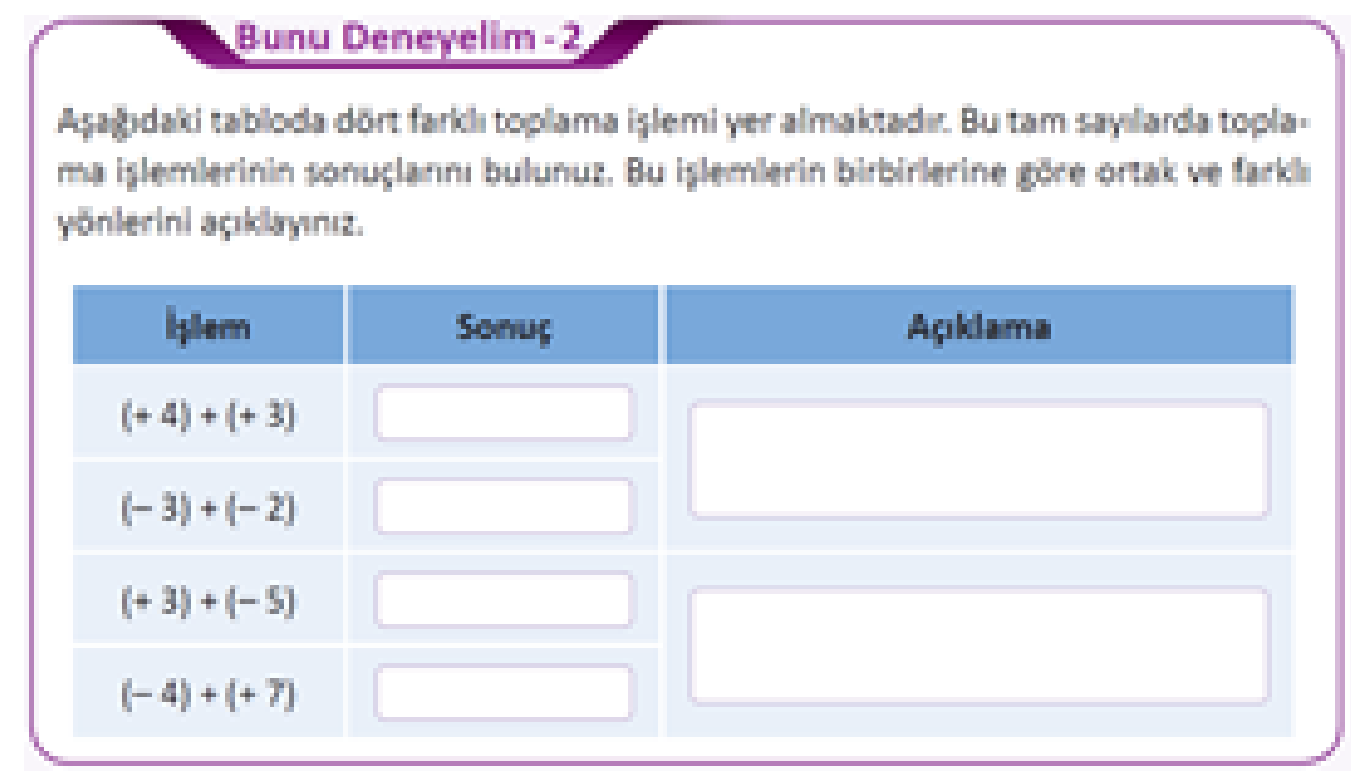

Etkinlik 2. (MEB, 2018 s. 365) 
Etkinlik 2'nin öğretmenlere göre amacına dair katılımcı cevaplarından elde edilen bulgular Tablo 3'te verilmiştir.

Tablo 3

Katılımcılarm Etkinlik 2'nin Amacına Dair Verdikleri Cevaplarm Kategorileri

\begin{tabular}{|c|c|c|c|}
\hline Kategori & Katılımcilar & $\mathbf{N}$ & Örnek cevaplar \\
\hline $\begin{array}{l}\text { Tam sayılarda } \\
\text { toplama } \\
\text { işleminde } \\
\text { işareti belirleme }\end{array}$ & $\begin{array}{l}\text { Ö1, Ö8, } \\
\text { Ö12, Ö13 }\end{array}$ & 4 & $\begin{array}{l}\text { Tam sayılarla toplama işleminde işaretini belirleme (Ö1) } \\
\text { Tam sayılarda toplama işleminde işaretlerin belirlenmesi(Ö8) } \\
\text { Tam sayılarda toplama işleminde işaret özellikleri (Ö12) } \\
\text { Pozitif iki tam sayının sonucunun pozitif, negatif iki tam } \\
\text { sayının toplamının negatif ve farklı işaretli iki tam sayının } \\
\text { toplamının sonucunun büyük sayının işareti olması gerektiğini } \\
\text { anlatmak (Ö13) }\end{array}$ \\
\hline $\begin{array}{l}\text { Aynı ve farklı } \\
\text { işaretli sayıların } \\
\text { toplamında } \\
\text { kural oluşturma }\end{array}$ & $\begin{array}{l}\text { Ö2, Ö3, } \\
\text { Ö4, Ö5 }\end{array}$ & 4 & $\begin{array}{l}\text { Aynı ve farklı işaretli tam sayıların toplamında bir kurala } \\
\text { varmak (Ö2) } \\
\text { Tam sayılarda toplama işlemini kavrar aynı ve zıt işaretli tam } \\
\text { sayılarda toplama yaparken nelere dikkat etmemiz gerektiğini } \\
\text { kavrar (Ö3) } \\
\text { Zıt işaretliler toplanırken çıkarma, aynı işaretliler toplanırken } \\
\text { direk topluyoruz bunu belirtmek için yapılmıs bir etkinlik(Ö4) } \\
\text { Tam sayılarda toplama işleminde işaretler aynı ise toplanır ve } \\
\text { sonuç sayılarla aynı işaretlidir. İşaretler zıt ise sayılar çıkarılır } \\
\text { ve mutlak değerce büyük olan sayının işareti alınır.(Ö5) }\end{array}$ \\
\hline $\begin{array}{l}\text { Tam sayılarda } \\
\text { toplama işlemi } \\
\text { yapabilme }\end{array}$ & $\begin{array}{l}\text { Ö6, Ö7, } \\
\text { Ö10, Ö14, } \\
\text { Ö15 }\end{array}$ & 5 & $\begin{array}{l}\text { Tam sayılarda toplama işlemi yapabilme (Ö6) } \\
\text { Tam sayılarda toplama işleminin öğretimi amaçlanmıştır. (Ö7) } \\
\text { Tam sayılarda toplama işlemi yapma (aynı işaretli ve farklı } \\
\text { işaretli tam sayıların toplamını yapma) (Ö10) } \\
\text { Tam sayılarda toplama işleminin öğretilmesi (Ö14) } \\
\text { Aynı ve zıt işaretli toplama işlemini kavrar (Ö15) }\end{array}$ \\
\hline $\begin{array}{l}\text { Doğal sayılarda } \\
\text { toplama } \\
\text { işlemini } \\
\text { kavrama }\end{array}$ & Ö9 & 1 & Doğal sayılarda toplama işlemini kavrama \\
\hline $\begin{array}{l}\text { Tam sayılarda } \\
\text { toplama } \\
\text { işlemine dönük } \\
\text { pekiştirme } \\
\text { etkinliği }\end{array}$ & Ö11 & 1 & Tam sayılarda toplama işlemine yönelik tekrar etkinliği \\
\hline
\end{tabular}

Tablo 3 incelendiğinde öğretmenlerin etkinliğin amacına dair genellikle tam sayılarda toplama işlemine vurgu yaptıkları görülmektedir. Ancak bazı katılımcılar "tam sayılarda toplama işlemi yapabilme" şeklinde genel ifadeler yazarken bazı katılımcıların ise daha özel amaçlar yazdıkları görülmektedir. Katılımcılardan 12' sinin öğrencinin aktif olduğu bir sürece işaret etmişlerdir. Ancak Ö7, Ö13 ve Ö14'ün diğer katılımcılardan farklı olarak öğretmeye yani öğretmenin aktif olduğu bir sürece işaret ettikleri görülmektedir. Katılımcıların verdiği cevaplar incelendiğinde dört katılımcının toplama işleminde sonucun işaretine vurgu yaptıkları $(1,8,12,13)$; dört tanesinin kural geliştirmeye vurgu yaptıkları $(2,3,4,5)$; beş tanesinin ise toplama işlemi yapabilmeyi genel olarak ifade ettikleri $(6,7,10,14,15)$ görülmektedir. Bir öğretmen etkinliği pekiştirme etkinliği olarak algılamış (Ö11); bir öğretmen ise etkinliğin amacını doğal sayılarda toplama işlemini kavrama (Ö9) olarak ifade etmiştir. 
Etkinlik 2'nin amacına dair verilen cevapların bilişsel talep düzeylerine göre sınıflara ayrılmış hali Tablo $4^{\prime}$ te verilmiştir.

Tablo 4

Etkinlik 2'nin Bilişsel Talep Düzeylerine Göre Katılıma Cevaplarını Analizi

\begin{tabular}{lll}
\hline Bilişsel talep düzeyi & Katılımcılar & N \\
\hline Ezberleme & Ö1, Ö8, Ö11 & 3 \\
Bağlantısız işlemler & Ö4, Ö5, Ö9, Ö10, & 4 \\
Bağlantılı işlemler & Ö12, Ö13, Ö3, Ö15 & 4 \\
Matematik yapma & Ö2 & 1 \\
Anlaşılmayan & Ö6, Ö7, Ö14 & 3 \\
\hline
\end{tabular}

Tablo 4 incelendiğinde Etkinlik 2'nin amacına dair katılımcı cevaplarının bağlantısız ve bağlantılı işlemler seviyesinde yoğunlaştığını söylemek mümkündür. Aynı kategoride değerlendirilen cevapların bazılarının farklı bilişsel talep düzeyine işaret ettiği görülmektedir. Örneğin Ö1, Ö8, Ö12 ve Ö13 “tam sayılarda toplama işleminde işareti belirleme" kategorisinde cevaplar vermişlerdir, ancak Ö1 ve Ö8 tam sayılarda işareti belirleme kategorisinde ezberleme seviyesinde amaçlar belirlemişken Ö12 ve Ö13 bağlantılı işlemler seviyesinde cevaplar vermişlerdir.

\section{Etkinlik 3'e Dair Bulgular}

Etkinlik 3, 8. Sınıf ders kitabı "cebirsel ifadelerle çarpma işlemi” başlığı altında yer almaktadir.

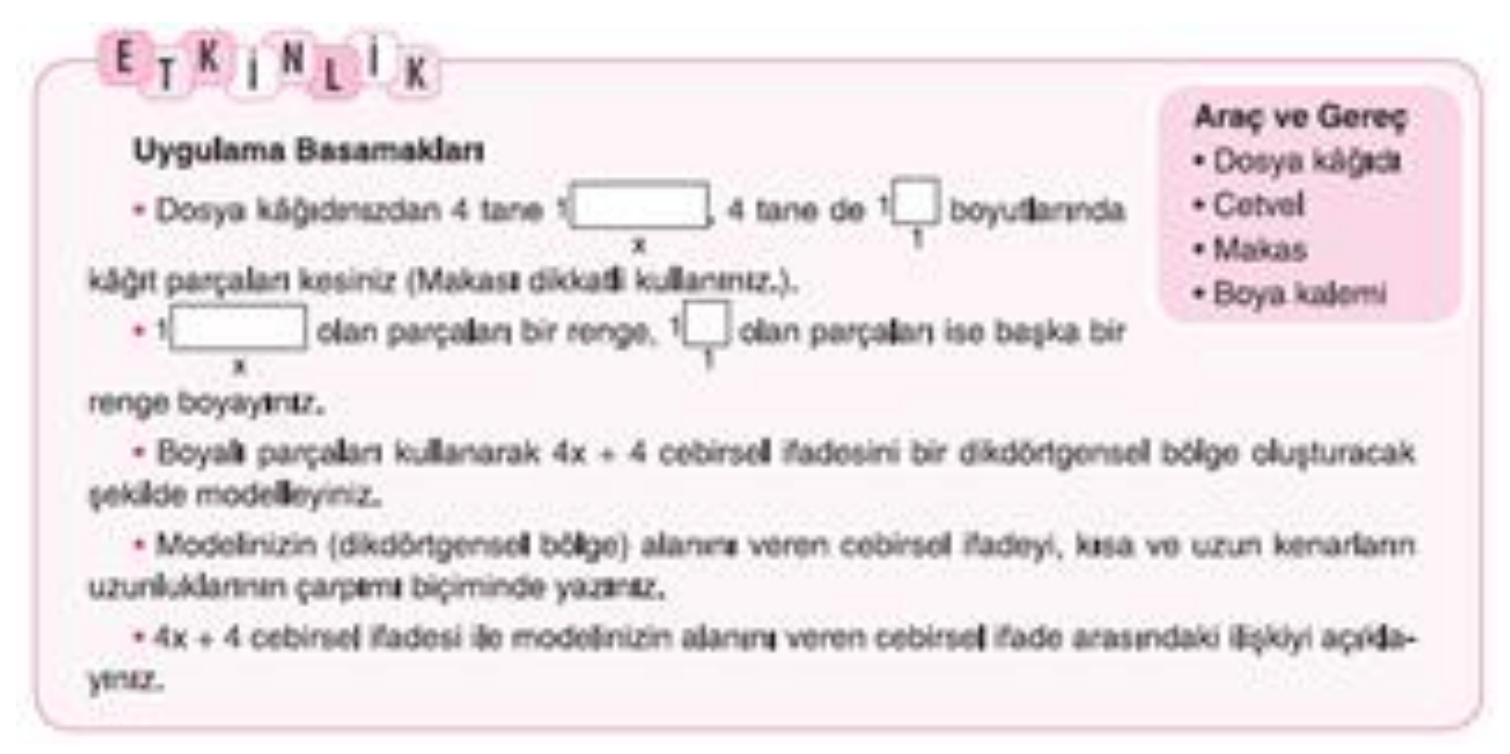

Etkinlik 3. (Sevgi yayınları 8. Sinıf s.140)

Etkinlik 3'ün öğretmenlere göre amacına dair katılımcı cevaplarından elde edilen bulgular Tablo 5'te verilmiştir. 
Tablo 5

Katılımcıların Etkinlik 3'ün Amacına Dair Verdikleri Cevaplarn Kategorileri

\begin{tabular}{|c|c|c|c|}
\hline Kategori & Katılımcılar & $\mathbf{N}$ & Örnek cevap \\
\hline $\begin{array}{l}\text { Bir doğal sayı ile bir } \\
\text { cebirsel ifadenin } \\
\text { çarpımı }\end{array}$ & Ö1, Ö8, Ö10 & 3 & $\begin{array}{l}\text { Bir doğal sayı ile bir cebirsel ifadenin çarpımının } \\
\text { kavratılması (Ö1) } \\
\text { Bir cebirsel ifade ile bir doğal sayının çarpımının } \\
\text { görselleştirilmesi (Ö8) } \\
\text { Bir doğal sayı ile bir cebirsel ifadeyi çarpma(Ö10) }\end{array}$ \\
\hline $\begin{array}{l}4 x+4=4(x+4) \\
\text { eşitliğinden }(x+1) \\
\text { alanlı } 4 \text { tane bölge } \\
\text { olduğunu buldurma }\end{array}$ & Ö2 & 1 & $\begin{array}{l}4 x+4=4(x+1) \text { 'e oradan da }(x+1) \text { alanlı } 4 \text { tane bölge } \\
\text { olduğunu buldurma amaçlıdır }\end{array}$ \\
\hline $\begin{array}{l}\text { Cebir kavramını } \\
\text { somutlaştırma }\end{array}$ & Ö3 & 1 & Öğrencilere cebir kavramının somutlaştırmak istenmiştir. \\
\hline $\begin{array}{l}\text { Cebirsel ifadelerde } \\
\text { paranteze alma }\end{array}$ & Ö2, Ö4, Ö12 & 3 & $\begin{array}{l}\text { Cebirsel ifadelerde paranteze alma (Ö4) } \\
4 x+4=4(x+4) \text { şeklinde ortak paranteze alma (Ö12) }\end{array}$ \\
\hline $\begin{array}{l}\text { Tam sayının cebirsel } \\
\text { ifade üzerine dağılma } \\
\text { özelliği }\end{array}$ & Ö5 & 1 & $\begin{array}{l}\text { Bu şekli oluşturup aslında şeklin alanını kısa ve uzun } \\
\text { kenarının çarpımı şeklinde yapmasını yani böyle yaparak } \\
\text { bir tam sayının cebirsel ifade üzerinde dağılma özelliği } \\
\text { olduğunu fark ettirmek istiyoruz. }\end{array}$ \\
\hline $\begin{array}{l}\text { Cebirsel ifade } \\
\text { oluşturma ve } \\
\text { anlamlandırma }\end{array}$ & Ö6 & 2 & Cebirsel ifade oluşturabilme ve anlamlandırabilme \\
\hline $\begin{array}{l}\text { Cebirsel ifadelerde } \\
\text { çarpma işlemi }\end{array}$ & Ö7, Ö13 & 2 & $\begin{array}{l}\text { Cebirsel ifadelerde çarpma işleminin öğretimi } \\
\text { amaçlanmıştır. (Ö7) } \\
\text { Cebirsel ifadelerde çarpma işlemini yapar (Ö13) }\end{array}$ \\
\hline $\begin{array}{l}\text { Cebirsel ifadelerle } \\
\text { işlemler }\end{array}$ & Ö9 & 1 & Cebirsel ifadeler ile işlemler \\
\hline Cebirsel ifadeler & Ö11 & 1 & Cebirsel ifadeler \\
\hline $\begin{array}{l}\text { Cebirsel ifadelerde } \\
\text { modelleme }\end{array}$ & Ö14, Ö15 & 2 & $\begin{array}{l}\text { Cebirsel ifadeleri kavrar ve modeller (Ö14) } \\
\text { Modelleme yöntemi ile cebirsel ifadeyi kavratma(Ö15) }\end{array}$ \\
\hline
\end{tabular}

Tablo 5 incelendiğinde en çok verilen cevabın "bir doğal sayı ile bir cebirsel ifadenin çarpımı" olduğu görülmektedir. İki öğretmenin sadece etkinliğin eylemsel amacını yazdıkları ve amacı cebirsel ifadelere genelleyemedikleri görülürken kimi öğretmenlerin cebirsel ifade, cebirsel ifadeyi kavratma, cebirsel ifadelerle işlemler gibi çok genel ifadeler yazdıkları görülmektedir. Bir öğretmen etkinliğin hem düşünsel hem eylemsel amacını yazmaya çalışmıştır (Ö5). Diğer katılımcı öğretmenlerin ise cebirsel ifadelerde çarpma işlemi ve modellemeye vurgu yaptıkları görülmektedir. Etkinlik 3'ün amacına dair verilen cevapların bilişsel talep düzeylerine göre sınıflara ayrılmış hali Tablo 6 'da verilmiştir.

Tablo 6 incelendiğinde Etkinlik 4'ün amacına dair katılımcı cevaplarının bilişsel talep düzeylerine göre ayrıldığında bağlantılı işlemler seviyesinde $(\mathrm{N}=7)$ bir yoğunlaşma olduğu görülmektedir. Ayrıca, bazı cevapların aynı kategoride olmalarına rağmen farklı bilişsel talep düzeylerinde olduğu görülmektedir. Örneğin; Ö2, Ö4 ve Ö12 ile aynı kategoride değerlendirilen cevap vermişken bilişsel olarak farklı talep düzeylerine işaret ettiği görülmektedir. 
Tablo 6

Etkinlik 4'ün Bilişsel Talep Düzeylerine Göre Katılımcı Cevaplarının Analizi

\begin{tabular}{lll}
\hline Bilişsel talep düzeyi & Kat1lımcılar & N \\
\hline Ezberleme & Ö6, & 1 \\
Bağlantısız işlemler & Ö4, Ö10, Ö12, Ö13 & 4 \\
Bağlantılı işlemler & Ö1, Ö8, Ö2, Ö3,Ö5, Ö14, Ö15 & 7 \\
Matematik yapma & & 0 \\
Anlaşılmayan & Ö7, Ö9, Ö11 & 3 \\
\hline
\end{tabular}

\section{Etkinlik 4'e Dair Bulgular}

Etkinlik 4, 6. Sınıf ders itabı "iki doğal sayının ortak katları" başlığı altında ve konu arasında verilmiştir.

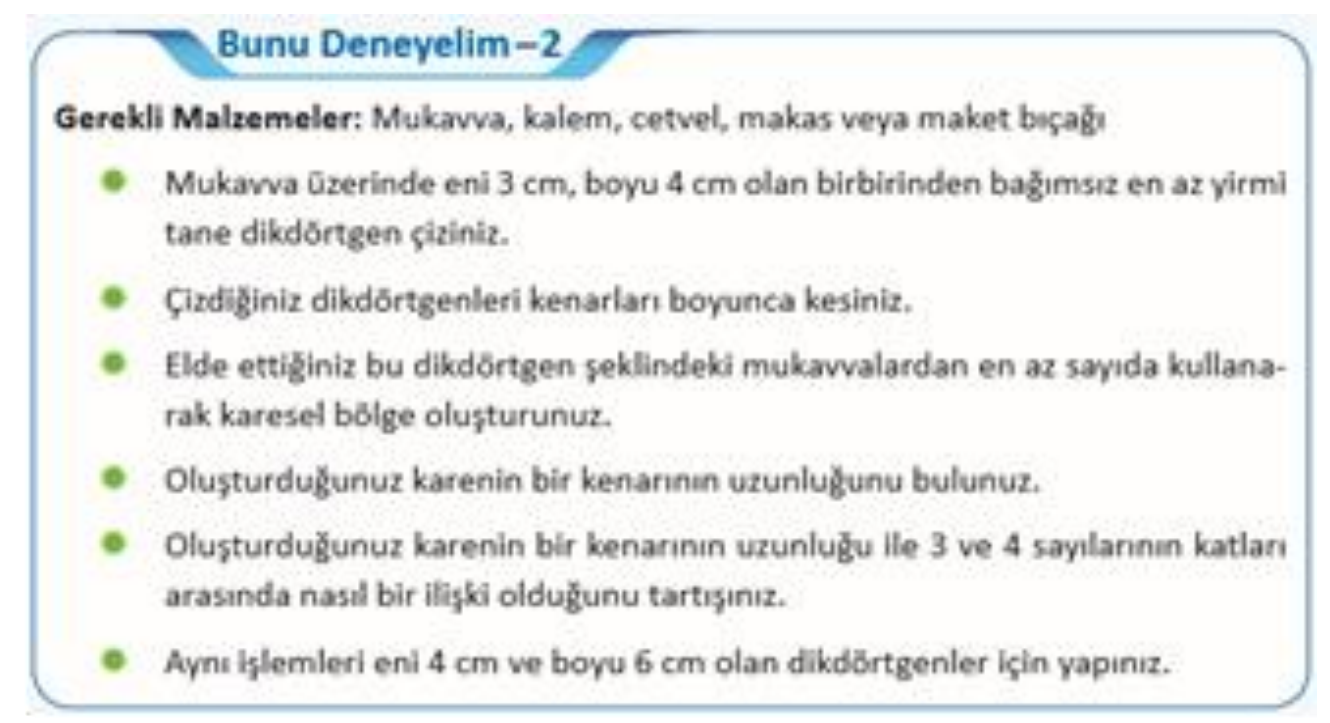

Etkinlik 4. ( MEB, 2018, s.85)

Etkinlik 4'ün amacına dair katılımcı cevaplarından elde edilen bulgular Tablo 7 ' de verilmiştir. Tablo 7 incelendiğinde öğretmenlerin genellikle Ekok (en küçük ortak kat) kavramına vurgu yaptıkları görülmektedir. Ancak bu doğrultuda verilen cevaplar incelendiğinde "Ekok'un hissettirilmesi", "Ekok'u nerde kullanırız?", "Ekok konusuna giriş" gibi ifadelere rastlanmaktadır. En çok tekrar eden cevabın Ekok'u kavratmak olduğu görülmektedir. Katılımcıların bazıları etkinliği konu girişine, bazıları konu sonuna konumlandırmıştır. Bu anlamda farklılaşan cevapların yanında bazı öğretmenler etkinliğin amacını tamamen farklı dile getirmiştir. Örneğin, bir öğretmen etkinliğin amacının, karenin dikdörtgenin özel hali olduğunu göstermek olduğunu ifade etmiştir. Bir başka öğretmen ise dikdörtgen ve kare şekilleri ile uzunluk ölçmenin bu etkinliğin amacı olduğunu ifade etmiştir. Bir öğretmen ise en büyük ortak bölen kavramına vurgu yapmıştır. Öğretmenlerin cevaplarından yalnızca bir tanesinde etkinliğin hem eylemsel hem düşünsel amacının bir arada verilmeye çalışıldığı görülmektedir (Ö15). Bir öğretmenin (Ö9) yalnızca eylemsel amacı yazdığı, geri kalan öğretmenlerin yalnızca düşünsel amacı yazmaya çalıştıkları görülmektedir. 
Tablo 7

Katılımcıların Etkinlik 4'ün Amacına Dair Verdikleri Cevaplarn Kategorileri

\begin{tabular}{|c|c|c|c|}
\hline Kategori & Katılımcilar & $\mathbf{N}$ & Örnek cevap \\
\hline $\begin{array}{l}\text { Ekok konusuna } \\
\text { giriş }\end{array}$ & Ö1, Ö11 & 2 & $\begin{array}{l}\text { Ekok konusunun hissettirilmesi (Ö1) } \\
\text { Ekok konusuna giriş için yapılan bir etkinlik (Ö11) }\end{array}$ \\
\hline Ekoku buldurmak & Ö2, Ö8, Ö13 & 2 & $\begin{array}{l}\text { İki sayının en küçük ortak katını (ekok) buldurmaktır. (Ö2) } \\
\text { İki doğal sayının ortak katlarını belirlemek (Ö8) } \\
\text { Öğrencilere ekoku buldurmak (Ö13) }\end{array}$ \\
\hline $\begin{array}{l}\text { Ekok'un } \\
\text { kullanımı }\end{array}$ & $\begin{array}{l}\text { Ö3, Ö12, } \\
\text { Ö15 }\end{array}$ & 3 & $\begin{array}{l}\text { Ekok'u nerde kullanırız (Ö3) } \\
\text { Ekok, ortak kat kullanabilme (Ö12) } \\
\text { Küçük dikdörtgenlerle karesel bölge oluşturmak. Bunu } \\
\text { yaparken ekok'u nasıl kullanacağını öğrenmek (Ö15) }\end{array}$ \\
\hline $\begin{array}{l}\text { Ekok'u } \\
\text { kavratmak }\end{array}$ & $\begin{array}{l}\text { Ö4, Ö5, Ö7, } \\
\text { Ö14 }\end{array}$ & 4 & $\begin{array}{l}\text { Ekok konusunu kavratmaktır (Ö4) } \\
\text { Burada öğrencilere ekok kavratılmaya çalışılmıştır (Ö5) } \\
\text { Ekok'un öğretimi amaçlanmıştır (Ö7) } \\
\text { Ekok kavramını anlaması (Ö14) }\end{array}$ \\
\hline $\begin{array}{l}\text { Ekok'u örnek } \\
\text { üzerinden } \\
\text { anlamlandırma }\end{array}$ & Ö6 & 1 & Ekok kavramını örnek üzerinden anlamlandırma. (Ö6) \\
\hline $\begin{array}{l}\text { Dikdörtgen-kare } \\
\text { ilişkisi }\end{array}$ & Ö9 & 1 & Dikdörtgenin özel halinin kare olduğunu göstermek \\
\hline Ebob bulma & Ö10 & 1 & En büyük ortak bölen işlemini yapar \\
\hline
\end{tabular}

Etkinlik 4'ün amacına dair verilen cevapların bilişsel talep düzeylerine göre ayrılmış hali Tablo 8' de verilmiştir.

Tablo 8

Etkinlik 4'ün Bilişsel talep düzeylerine göre katılımcı cevaplarının analizi

\begin{tabular}{lll}
\hline Bilişsel talep düzeyi & Katılımcılar & N \\
\hline Ezberleme & Ö1, Ö4, Ö5, Ö11, & 4 \\
Bağlantısız işlemler & Ö8, Ö10 & 2 \\
Bağlantılı işlemler & Ö3, Ö12, Ö15 & 3 \\
Matematik yapma & Ö2, Ö6, Ö13 & 3 \\
Anlaş1lmayan & Ö7, Ö9, Ö14 & 3 \\
\hline
\end{tabular}

Tablo 8 incelendiğinde Etkinlik 4'ün amacına dair katılımcı cevaplarının bilişsel talep düzeylerine göre incelendiğinde seviyelere göre neredeyse eşit bir şekilde dağıldı̆̆ı görülmektedir.

\section{Tartışma}

Bu çalışma kapsamında 15 ortaokul matematik öğretmenine 4 etkinlik verilmiş ve bu etkinliklerin amaçlarını yazmaları istenmiştir. Bulgular incelendiğinde, öğretmenlerin etkinliklerin amacına dair verdikleri cevaplardan ilk göze çarpan nokta, öğretmenlerin etkinliğin amacını çok genel olarak ifade ettikleridir. Genellikle etkinliğin ilgili olduğu kazanımı ifade eden bu cevapların problemli olduğu taraf, bir etkinliğin amacı olmak için fazla genel ve fazla kapsamlı olmalarıdır. Zira, Ainley ve diğerleri (2006), bir etkinliğin veya görevin amacının ilgili kazanımlarla (Learning Objectives) paralel ancak bundan farklı bir bileşen olduğunu belirtmektedir. Örneğin, etkinlik 3’ün 
amacını Ö9, "cebirsel ifadelerde işlemler" olarak ifade etmiştir. Oysa cebirsel ifadelerde işlemler başlı̆̆ programında 7 ve 8 . sınıfta olmak üzere toplam 3 ayrı kazanımda verilmektedir (MEB, 2018). Aynı etkinlikte "cebirsel ifadeler", "cebirsel ifadelerde çarpma işlemini yapar" şeklindeki özelleştirilemeyen cevaplara rastlanırken bu durumun diğer etkinliklerin amaçlarını yazarken de karşımıza çıktığı görülmektedir. Örneğin, etkinlik 2'nin amacını Ö7,"tam sayılarda toplama işleminin öğretimi amaçlanmıştır" olarak ifade ederken, etkinlik 4'ün amacı için Ö4, “Ekok konusunu kavratmak" ifadesini kullanmıştır. Etkinlikler incelendiğinde her birinin bahsedilen kazanımların bir boyutu ile ilgili olduğu açıktır. Ancak bahsedilen gruba giren katılımcı cevaplarının etkinliğin özellikle ilgili olduğu noktayı kaçırdıkları ve/veya dikkate almadıkları görülmektedir.

Katılımcıların cevaplarında dikkat çeken bir başka bulgu ise aynı etkinlik için öğretmenlerin farklı etkinlik türlerine işaret eden cevaplar vermeleridir. Katılımcıların bazılarının "kavratmak”, "öğretmek” gibi yeni bir bilgi oluşturmaya referans veren cevaplar verirken kimilerinin "tekrar etkinliği” gibi cevaplarla pekiştirmeye dönük bir etkinlik olarak algıladıkları görülmektedir. Literatürde etkinliklerin türlerine göre yeni bir kazanıma dönük etkinlik, kavram yanılgısını giderme, alanın epistemolojik yapısına dair farkındalık sağlama ve pekiştirme amaçlarından bir veya bir kaçına yönelik olma yönleriyle tasnif edilebileceği vurgulanmaktadır (Özmantar ve Bingölbali, 2009). Etkinliklerin yapısı gereği bu türlerden biri veya birkaçı için uygun etkinlikler olabileceği bilinmektedir (Bozkurt, 2018). Ancak verilen bir etkinlik için öğretmenlerin cevaplarının farklılık göstermesi bu yönüyle de bir kafa karışıklığının olduğu şeklinde yorumlanabilir. Katılımcıların aktif öğretmenlik yaptığı düşünülürse bu ve benzer etkinlikleri yanlış bağlamlarda uygulayarak verimsiz bir etkinlik süreci geçirmeleri beklenebilir. Nitekim Bozkurt ve Kuran (2016) öğretmenlerin etkinlikleri sınıflarında uygulamayı denediklerini ancak süreç içerisinde yaşadıkları başarısızlıkları göz önünde bulundurarak bir süre sonra etkinlik uygulamaktan vazgeçtiklerini belirtmektedir. Birçok ders kitabında etkinlikler öğretim akışının dışında ek olarak verilmektedir (örn. Sevgi Yayınları, MEB 6). Bu durumda etkinliğin yanlış veya uygun olmayan bir amaçla kullanılması ve verimsiz süreçler doğurması olası bir durumdur.

Etkinlik 3 ve $4^{\prime}$ te ilk iki etkinliğe göre cevapların daha çok farklılaştı̆̆ görülmektedir. Şöyle ki, Etkinlik-3 için öğretmenler 10 farklı kategoride cevaplar vermişlerdir. Etkinlik-4 için 7 farklı kategoride cevaplar verilmiş ancak bilişsel talep düzeylerine göre neredeyse homojen bir şekilde cevaplar dağılmıştır. Bu etkinliklerin sonunda öğrencilerden ilişkilendirme yapmaları, aynı durumu farklı örneklerde denemeleri ve genellemeye varmalarının beklendiği görülmektedir. Dolayısıyla, bu etkinliklerin bilişsel taleplerinin (Swan ve ark., 2000) daha yüksek olduğu söylenebilir. $\mathrm{Bu}$ bulgu, Swan ve arkadaşları'nın (2000) çalışmasında bir etkinliğin sınıfta uygulanması esnasında öğretmenlerle öğrencilerin amaca dönük alg1 ve beklentilerinin farklı olduğunu ifade etmektedirler. Algıdaki bu farklılaşma matematiksel anlamda zengin etkinlikler için daha fazla olduğu bulgusu ile beraber değerlendirildiğinde, matematiksel anlamda zengin bir etkinliğin amacının, süreç içinde değişmesinin veya yanlış algılanmasının daha olası olduğu düşünülebilir.

Araştırmadan elde edilen bulgular incelendiğinde katılımcı cevaplarının bilişsel talep düzeylerine göre farklılaştığını söylemek mümkündür. Rençber ve Sezer (2018), 
ders kitaplarında yer alan etkinliklerin bilişsel talep düzeylerinin öğretim programında yer alan kazanımların bilişsel talep düzeylerine göre daha düşük seviyede olduğunu göstermişlerdir. Dolayısıyla, farklı kitaplarda aynı kazanımlar olmakla beraber bilişsel seviyelerin değiştiği görülmektedir. Bu araştırmanın bulgularından ise kitap ve etkinlikler aynı olsa bile bilişsel seviyenin öğretmene göre değişebileceği görülmektedir. Bu durumda, farklı öğretmenle eğitim gören öğrencilerin bilişsel bağlamda farklı öğrenme çıtıları olabilir (Ubuz ve Sarpkaya, 2014). Bu ise aynı eğitim süreçlerinden geçen öğrencilerin ilgili matematiksel kavramlara ilişkin farklı bilişsel düzeylerde olmalarına sebep olabilir. Buradan özellikle ders kitaplarında verilen etkinliklerle neyin amaçlandığının daha açık ve anlaşılır bir şekilde ifadesinin önemi ortaya çıkmaktadır.

\section{Sonuç ve Öneriler}

Öğretmenlerin verdikleri cevaplarda büyük oranda etkinliğin düşünsel amacını yazmaya çalıştıkları görülmektedir. Öğretmenlerden, eylemsel amacı ve düşünsel amacı beraber değerlendirenlerin sayısının az olduğu görülmektedir. Bu bulgudan yola çıkarak öğretmenlerin etkinliğin eylemsel amacını belirleyemedikleri veya farkında olmadıkları söylenemez. Ancak etkinliğin amacını yazarken her iki amacı ayrı ayrı dile getirmek öğretmenlerin etkinlikleri daha sağlıklı değerlendirmelerine olanak sağlayabilir.

Bulgular incelendiğinde öğretmenlerin kendilerine verilen etkinliğin amacına dönük birbirinden oldukça farklı cevaplar verdikleri görülmektedir. Dolayısıyla, alan yazında etkinliklerin öğretmen ve öğrencilerce algılanan amaçlarının farklı olacağı sonucunun yanında (Ainley ve Margolinas, 2013) etkinliği tasarlayan ile uygulayan arasında da bu farkın oluşabileceği görülmektedir. Bu bakımdan, etkinliğin amacının süreç içinde Şekil 2'de verilen aşamalardan geçebilir.

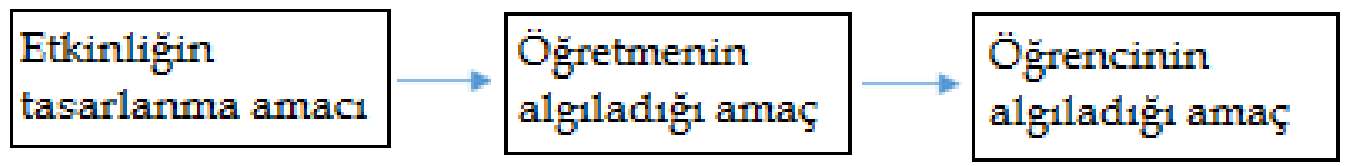

Şekil 2. Etkinliğin tasarlanma amacının geçirdiği süreçler

Tasarlanan bir etkinliğin, tasarlandı̆̆ 1 amaca hizmet edebilmesi Şekil 2'de de görüldüğü gibi iki varsayıma dayanmaktadır:

Varsayım 1: Öğretmen etkinliğin amacını doğru anlamıştır ve öğrencilere doğru anlatmıştır.

Varsayım 2: Öğrenciler etkinliğin amacını doğru anlamıştır.

Alan yazında bu varsayımlardan ikincisinin, giriş bölümünde bahsedilen hususlar nedeniyle her zaman doğru olmadığı vurgulanmaktadır (ör. Choy, 2018). Araştırmanın bulguları, Varsayım 1'in de her zaman doğru olmayacağına dair fikir vermektedir. $\mathrm{O}$ halde, eğitsel dokümanlarda hazır olarak sunulan bir etkinliğin amacını öğretmen farklı yorumlayarak öğrencileri farklı bir amaca yönlendirebilir veya öğrenciler farklı bir algılama sonucu bağlamın dışına çıkabilirler. Bu iki riski ortadan kaldırmak öncelikle öğretmenlerin etkinliğin amaçları konusunda bilgi ve deneyimlerinin arttırılması veya etkinliğin yer aldığı kaynakta bu etkinliğin amacının herkes için açık hale getirilmesi ile mümkündür (Swan vd., 2000). Yapılandırmacı 
yaklaşıma göre hazırlanmış ders kitaplarının birçoğunda etkinliklere yer verilmektedir. Ancak yine birçok ders kitabı veya yardımcı kitaplardaki yer verilen etkinliğin amacı açıkça belirtilmediği görülebilmektedir (Özgeldi ve Esen 2010; Bozkurt, 2012). Bu durumda da öğretmenin verilen etkinliğin hangi amaçlar için kullanmaya uygun olduğunu belirlemesi gerekebilmektedir. Öğretmenler için profesyonel standartlar kısminda NCTM (National Council of Teachers of Mathematics, 1991) öğretmenlerin temel sorumluluğunun öğrencileri için uygun etkinlikler seçme ve geliştirme olduğunu belirtmektedir. Doğru etkinlik seçme öncelikle etkinliğin hangi amaçlar için kullanmaya uygun olduğunu belirlemek ile mümkün olabilmektedir.

Etkinliğin tasarımı için birden fazla amaçtan ve birden fazla boyuttan bahsedilmektedir (Özmantar ve Bingölbali, 2009). Hatta, tasarım amacıyla ilgili yaşanan bu durumun karmaşık bir hal aldığı iddia edilebilir. Bu karmaşanın nedeni, etkinliğin kendi başına bir yapı olduğu gibi bir algıya kapılmaktan kaynaklanabilir. Zira, etkinlik istenilen öğretimsel kazanımı vermek için bir araçtır (Jonassen, 1992; Mayes, 1992). Bu perspektifle bakıldığında bir araç olarak etkinliğin amacı yerine etkinliği tasarlayanın amacı, etkinliği uygulayanın (öğretmen) amacı ve etkinliğe muhatap olanın (öğrencinin) amacı olarak ayrı ayrı değerlendirmek, bahsedilen karmaşanın ortadan kaldırılmasını sağlayabilir.

Etkinlik sürecinin beklenen aşamaları; etkinliği tasarlayanın, uygulayanın ve etkinliğe muhatap olanın amacı Şekil 2'deki gibi sıralıdır. Etkinliği tasarlayan ve etkinliği uygulayanın amacının aynı olması beklenir. Ancak alan yazında öğretmenlerin etkinlikler ile ilgili algı ve bilgilerinin sınırlılığına işaret eden çalışmalar düşünüldüğünde (Bozkurt, 2018) bunun iyi niyetli bir temenniden öteye geçmeyeceği görülmektedir. Ayrıca, öğretmenlerin bir etkinliği bilinçli bir şekilde farklı bir amaçla kullanması da olası bir durumdur. Dolayısıyla, etkinliklerin amacının tasarlayan ve uygulayan arasında değişime uğraması beklenen bir durum olarak karşımıza çıabilmektedir.

Etkinliğe muhatap olacak olan öğrencilerin etkinliği tasarlayanın veya uygulayanın amacını bilmeleri her zaman mümkün değildir. Ancak etkinlik öğrencilere bir takım hedefler koyar ve bu hedeflere ulaşmak öğrencinin amacı olarak tarif edilebilir. Bu hedeflerin etkinliğin tasarlanma ve uygulanma amacı ile birebir aynı olması beklenemez. Dolayısıyla, bu aşamada da etkinliğin amacının değiştiği görülebilir.

Son olarak, "etkinliğin amacı" kavramının kullanılması beraberinde "etkinliğin hangi amacı?" sorusunu gündeme getirmekte ve bu soruya verilen cevaplar etkinliğin amacı noktasında çeşitlendikçe durumun anlaşılması zorlaşabilmektedir. Bu noktadan hareketle etkinlik için genel geçer ve değişmez bir amaçtan bahsetmek yerine etkinliği bir araç olarak değerlendirip etkinliği tasarlayan, uygulayan veya muhatap olanların amaçlarından bahsetmek daha yerinde olacaktır.

\section{Kaynakça}

Ainley, J.,Pratt, D., and Hansen, A. (2006). Connecting engagement and focus in pedagogic task design. British Educational Research Journal, 32(1), 23-38. https:// doi.org/10.1080/01411920500401971

Ainley, J., and Margolinas, C. (2013). Accounting for student perspectives in task design. En C.Margolinas, A. Watson, M. Ohtani, J. Ainley, J. B. Frant, M. 
Doorman, C. Kieran, A. Leung, P. Sullivan, D. Thompson y Y. Yang (Eds.). Proceedings of ICMI Study 22. Task Design in Mathematics Education (pp. 151152). Oxford, UK: ICMI.

Bayazit, I. (2013). Quality of the tasks in the new Turkish elementary mathematics textbooks: The case of proportional reasoning. International Journal of Science and Mathematics Education, 11(3), 651-682. https:/ / doi.org/10.1007/s10763-0129358-8

Bozkurt, A. (2012). Matematik öğretmenlerinin matematiksel etkinlik kavramına dair algıları. Ĕgitim ve Bilim, 37(166). 101-115.

Bozkurt, A. (2018). Ortaokul 6. sınıf matematik ders kitabındaki etkinliklerin amaç, öğrenci çalışma biçimi ve uygulanabilirlik yönleriyle

değerlendirilmesi. Elektronik Sosyal Bilimler Dergisi, 17(66), 536-549. https:// doi.org/10.17755/esosder.342636

Bozkurt, A., ve Kuran, K. (2016). Öğretmenlerin matematik ders kitaplarındaki etkinlikleri uygulama ve etkinlik tasarlama deneyim ve görüşlerinin incelenmesi. Ege Ĕ̈itim Dergisi, 17(2), 377-398.

https:// doi.org/10.12984/egeefd.280750

Choy, B. H. (2016). Snapshots of mathematics teacher noticing during task design. Mathematics Education Research Journal, 28(3), 421-440. https:// doi.org/10.1007/s13394-016-0173-3

Choy, B. H. (2018). From task to activity: noticing affordances, design, and orchestration. Mathematics Instruction: Goals, Tasks and Activities-Yearbook 2018, Association of Mathematics Educators, 11. https:// doi.org/10.1142/9789813271678_0002

Cırıtcı, H., Gönen, İ., Araç, D., Özarslan, M., Pekcan, N., ve Şahin, M., (2018). Ortaokul ve Imam Hatip Ortaokulu Matematik Ders kitabr 5. Devlet Kitaplar1. Ankara.

Clarke, D., and Roche, A. (2018). Using contextualized tasks to engage students in meaningful and worthwhile mathematics learning. The Journal of Mathematical Behavior, 51, 95-108. https:// doi.org/10.1016/j.jmathb.2017.11.006

Coles, A., and Brown, L. (2016). Task design for ways of working: making distinctions in teaching and learning mathematics. Journal of Mathematics Teacher Education, 19(2-3), 149-168. https:/ / doi.org/10.1007/s10857-015-9337-4

Daher, W., Anabousy, A., and Jabarin, R. (2018). Metacognition, positioning and emotions in mathematical activities. International Journal of Research in Education and Science, 4(1), 292-303. https://doi.org/10.21890/ijres.383184

Doyle, W. (1983). Academic work. Review of educational research, 53(2), 159-199. https:/ / doi.org/10.3102/00346543053002159

Dweck, C. S. (2000). Self theories: Their role in motivation, personality, and development. Philadelphia, VA: Psychology Press.

Fraenkel, J. R., Wallen, N. E., and Hyun, H. H. (2011). How to design and evaluate research in education. New York: McGraw-Hill Humanities /Social Sciences/ Languages.

Henningsen, M., and Stein, M. K. (1997). Mathematical tasks and student cognition: Classroom-based factors that support and inhibit high-level mathematical thinking and reasoning. Journal for research in mathematics education, 524-549. https:// doi.org/10.5951/jresematheduc.28.5.0524 
Jonassen, D. H. (1992). What are cognitive tools?. In Cognitive tools for learning (pp. 16). Springer, Berlin, Heidelberg. https:// doi.org/10.1007/978-3-642-77222-1_1

Kerpiç, A., ve Bozkurt, A. (2011). Etkinlik tasarım ve uygulama prensipleri çerçevesinde 7. Sınıf matematik ders kitabı etkinliklerinin değerlendirilmesi. Mustafa Kemal Üniversitesi Sosyal Bilimler Enstitüsü Dergisi, 8(16), 303-318.

Kieran, C., Doorman, M., and Ohtani, M. (2015). Frameworks and principles for task design. In Task Design In Mathematics Education (pp. 19-81). Springer International Publishing.

Komatsu, K., and Jones, K. (2019). Task design principles for heuristic refutation in dynamic geometry environments. International Journal of Science and Mathematics Education, 17(4), 801-824. https://doi.org/10.1007/s10763-0189892-0

Liljedahl, P.,Chernoff, E., and Zazkis, R. (2007). Interweaving mathematics and pedagogy in task design: A tale of one task. Journal of Mathematics Teacher Education, 10(4-6), 239-249. https:/ / doi.org/10.1007/s10857-007-9047-7

Mayes, J. T. (1992). Cognitive tools: A suitable case for learning. In Cognitive tools for learning (pp. 7-18). Springer, Berlin, Heidelberg. https://doi.org/10.1007/9783-642-77222-1_2

MEB, (2016), 6. Sinıf Matematik Ders Kitabı. Ankara: Sevgi yayınları

MEB, (2018), 6. Sinıf Matematik Ders Kitabı. Ankara: Devlet Kitapları

MEB (2018). Matematik dersi öğretim programı (1, 2, 3, 4, 5, 6, 7 ve 8. Sinıflar). Ankara.

Miles, M. B., and Huberman, M. (1994). Qualitative data analysis: an expanded sourcebook (2. ed.). London.

National Council of Teachers of Mathematics (NCTM), (1991). Professional standards for teaching mathematics. Reston, VA: The National Council of Teachers of Mathematics.

Newman, D., Griffin, P., and Cole, M. (1989). The construction zone: Working for cognitive change in school. Cambridge, MA: Cambridge University P

Ojose, B. (2015). Students' misconceptions in mathematics: Analysis of remedies and what research says. Ohio Journal of School Mathematics, 72, 30-34.

Özgeldi, M., and Esen, Y. (2010). Analysis of mathematical tasks in Turkish elementary school mathematics textbooks. Procedia-Social and Behavioral Sciences, 2(2), 2277-2281. https:// doi.org/10.1016/j.sbspro.2010.03.322

Özgen, K. (2017). Matematiksel Öğrenme Etkinliği Türlerine Yönelik Kuramsal Bir Çalışma: Fonksiyon Kavramı Örneklemesi. Abant İzzet Baysal Üniversitesi Ĕ̆itim Fakültesi Dergisi, 17 (3), 1437-1464. https:// doi.org/10.17240/aibuefd.2017.17.31178-338839

Özmantar, M. F., and Bingölbali, E. (2009). Etkinlik tasarımı ve temel tasarım prensipleri. M. F. Özmantar ve E. Bingölbali (Ed.), Matematiksel Zorluklar ve Çözüm Önerileri (s.313-348). Ankara: Pegem Yayınları.

Özmantar, M. F., ve Aslan, B. Matematiksel etkinliklerin uygulanması sırasında ortaya çıkan öğretmen ve öğrenci rolleri. International Journal of Social Science Research, 6(1), 1-23.

Reçber, H., ve Sezer, R. (2018). 8. sınıf matematik ders kitabındaki etkinliklerin bilişsel düzeyinin programdakilerle karşılaştırılması, Ankara Üniversitesi Ĕ̆itim Bilimleri Fakültesi Dergisi, 51(1), 55-76. https:// doi.org/10.30964/auebfd.405848 
Robson, C. (2009). Real world research: a resource for social scientists and practitioner researchers. Malden, MA: Blackwell.

Rollard, R. G. (2012). Synthesizing the evidence on classroom goal structures in middle and secondary schools: A meta-analysis and narrative review. Review of Educational Research, 82 (4), 396-435. https:/ / doi.org/10.3102/0034654312464909

Stein, M. K., Grover, B. W., and Henningsen, M. (1996). Building student capacity for mathematical thinking and reasoning: An analysis of mathematical tasks used in reform classrooms. American educational research journal, 33(2), 455-488. https:// doi.org/10.3102/00028312033002455

Stein, M. K., Smith, M. S., Henningsen, M. A. and Silver, E. A. (2000). Implementing standards-based mathematics instructions: a case book for Professional development. New York: Teachers College.

Stein, M. K., and Smith, M. S. (1998). Mathematical tasks as a framework for reflection: From research to practice. Mathematics teaching in the middle school, 3(4), 268-275.

Swan, M., Bell, A., Phillips, R., and Shannon, A. (2000). The purposes of mathematical activities and pupils' perceptions of them. Research in Education, 63(1), 11-20. https:/ / doi.org/10.7227/RIE.63.2

Ubuz, B., ve Sarpkaya, G. (2014). İlköğretim 6. sınıf cebirsel görevlerin bilişsel istem seviyelerine göre incelenmesi: Ders kitapları ve sınıf uygulamaları. İlköğretim Online, 13(2), 594-606.

Uğurel, I., Bukova-Güzel, E., ve Kula, S. (2010). Matematik öğretmenlerinin öğrenme etkinlikleri hakkındaki görüş ve deneyimleri. Dokuz Eylül Üniversitesi Buca Ĕ̆itim Fakültesi Dergisi, (28), 103-123.

Watson, A., and Ohtani, M., (2015). Task design in mathematics education. An ICMI Study, 22. https:/ / doi.org/10.1007/978-3-319-09629-2

Watson, A. (2016). Parameters for practice and research in task design in mathematics education. In 13th International Congress on Mathematical Education, Hamburg, Germany.

Younger, M. (2018). Spatial skills activities in the middle school mathematics teachers' toolkit: The impact of spatial skill activities on mathematical thinking (Doctoral dissertation). University of Toronto, Toronto, ON.

\section{Summary}

\section{Introduction}

A review of relevant studies reveals that teachers and students have different perceptions of activities' purposes in math classes. However, most studies assume that the teacher who designs the activity and the teacher who implements it has a common purpose. Furthermore, the purposes of activities in textbooks and other learning materials are not clearly stated. In this context, this study intends to show how secondary school teachers of mathematics perceive the cognitive objectives of a particular activity given to them. 


\section{Method}

The study was designed as a descriptive research. The study population comprises of 15 secondary school mathematics teachers attending a math teacher Post-Graduate program in the fall semester of the 2018-2019 academic year. Within the context of the study, a written form was prepared containing four activities randomly selected from text books and an instruction saying "Please write an objective for each of these activities." The content analysis and descriptive analysis methods were used for data analysis. Within the context of content analysis, each activity was analyzed in terms of the purposes determined by the participants. These purposes were then divided into categories. Six categories were created for the first activity, five were created for the second activity, ten were created for the third activity and eight categories were created for the fourth activity. In the context of descriptive analyses, each activity which the participants were required to write purposes for were analyzed according to the cognitive demands taxonomy. According to this taxonomy, the answer given by each participant was categorized according to the cognitive processes of recalling, comprehending, implementing, analyzing, evaluating and creating.

\section{Results}

It can be inferred on the basis of the responses given by the participants that teachers have disparate views of the purposes of the same activities. While teachers agree about the learning and sub-learning areas to which the activities are related, they disagree on the specific purpose of the given activities. A categorization of the responses of the teachers about the purposes of the four activities revealed that the responses could be divided into 29 different categories. Furthermore, the results demonstrated that teacher responses particularly showed discrepancies in cases where they expected students to make associations, represent the case through different examples and make generalizations. Teacher responses also revealed a propensity to perceive the activities as representing different cognitive skills.

\section{Discussion}

The findings show that teachers provided different responses about the purposes of the activities given to them. In addition, according to the cognitive demands, the responses of the participants can also be categorized into different groups. In this case, students taught by different teachers may have different learning outcomes. This may cause the students who go through the same educational processes to be at different cognitive levels for the relevant mathematical concepts. In that regard, it becomes especially important that the purposes of activities in text books need to be stated clearly and succinctly. Therefore, different perceptions as to the objectives of the activities can also exist between the designer and the implementer of those activities, in addition to the different perceptions of teachers and students towards the purposes of an activity.

\section{Educational Implications}

This study aimed to examine how mathematics teachers perceive the purposes of text book activities. In this respect, the objective of an activity can go through the following stages in the process. 


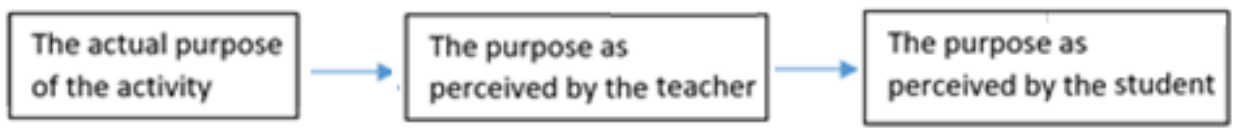

Figure 1. The purpose of the activity, its perception by teachers and students

The anticipated stages of the activity process are defined by the perceptions of its purposes by the designer, the implementer and those who are exposed to it. The designer and the implementer of the activity are mostly expected to be the same person. However, given in the studies that indicate the limitation of teachers' perceptions and knowledge about activities, it seems that this is merely a wishful thinking. From this point of view, it is more appropriate to view activities as a tool, and to focus on the objectives of those who design, implement or engaged with them rather than assuming the need to look for immutable purposes for an activity.

\section{Araştırmanın Etik Taahhüt Metni}

Yapılan bu çalışmada bilimsel, etik ve alıntı kurallarına uyulduğu; toplanan veriler üzerinde herhangi bir tahrifatın yapılmadığı, karşılaşılacak tüm etik ihlallerde "Cumhuriyet Uluslararası Eğitim Dergisi ve Editörünün" hiçbir sorumluluğunun olmadığ1, tüm sorumluluğun Sorumlu Yazara ait olduğu ve bu çalışmanın herhangi başka bir akademik yayın ortamına değerlendirme için gönderilmemiş olduğu sorumlu yazar tarafından taahhüt edilmiştir.

\section{Authors' Biodata/ Yazar Bilgileri}

Mehmet GÜZEL Matematik Eğitimi alanında akademik çalışmalar yapmaktadır. Çalışma alanları arasında öğretimsel etkinlikler ve materyal geliştirme yer almaktadır.

Mehmet Guzel He conducts academic studies in the field of Mathematics Education. His areas of study include instructional activities and material development.

Ali BOZKURT Gaziantep Üniversitesi Eğitim Fakültesi'nde profesör doktor olarak görev yapmaktadır. Matematik Eğitimi alanında akademik çalışmalar yapmaktadır. Çalışma alanları arasında öğretmen eğitim, öğretimsel etkinlikler ve materyal geliştirme yer almaktadır.

Ali Bozkurt works as a professor doctor in Gaziantep University Faculty of Education. He conducts academic studies in the field of Mathematics Education. His fields of study include teacher education, instructional activities and material development.

Mehmet Fatih ÖZMANTAR Gaziantep Üniversitesi Eğitim Fakültesi'nde profesör doktor olarak görev yapmaktadır. Matematik Eğitimi alanında akademik çalışmalar yapmaktadır. Çalışma alanları arasında öğretmen eğitim, öğretimsel etkinlikler ve matematik eğitiminde sosyo-kültürel yaklaşımlar yer almaktadır.

Mehmet Fatih Özmantar works as a professor doctor in Gaziantep University Faculty of Education. He conducts academic studies in the field of Mathematics Education. His fields of study include teacher education, instructional activities and socio-cultural approaches in mathematics educations. 